\section{Self-reseeding annual legumes evaluated as cover crops for untilled vineyards}

by Glenn McGourty, James Nosera,
Steven Tylicki and Agnes Toth

Self-reseeding annual cover crops can regenerate in subsequent years without tilling the seedbed and can be part of a strategy to protect vineyard soil from erosion. We compared 22 such cultivars in a 1-yearold 'Syrah' wine-grape vineyard located at 1,400 feet in Lake County. We found significant differences between species in the amount of biomass produced in 2004 and 2005. All of the species studied were relatively low statured and fit well in vineyard middles. Pressure bomb readings taken after the cover crops stopped growing showed that with a dry spring (2004), vines with cover crops were modestly more stressed than those under tillage prior to July irrigations, but after irrigation the cover-cropped vines were slightly less stressed. In 2005, which had rainfall in late spring, there were no differences in vine water status throughout the season. We conclude that water use by the cover crop must have been relatively low and did not result in excessive vine water stress.

$\mathrm{D}$ uring the past 15 years, cover crops have become widely used in California as a vineyard floor management practice (McGourty 1994, 2004). Cover crops protect vineyard soil from erosion, improve soil fertility and tilth, serve as habitat and food for beneficial insects and mites, and provide firm footing during wet weather. They are

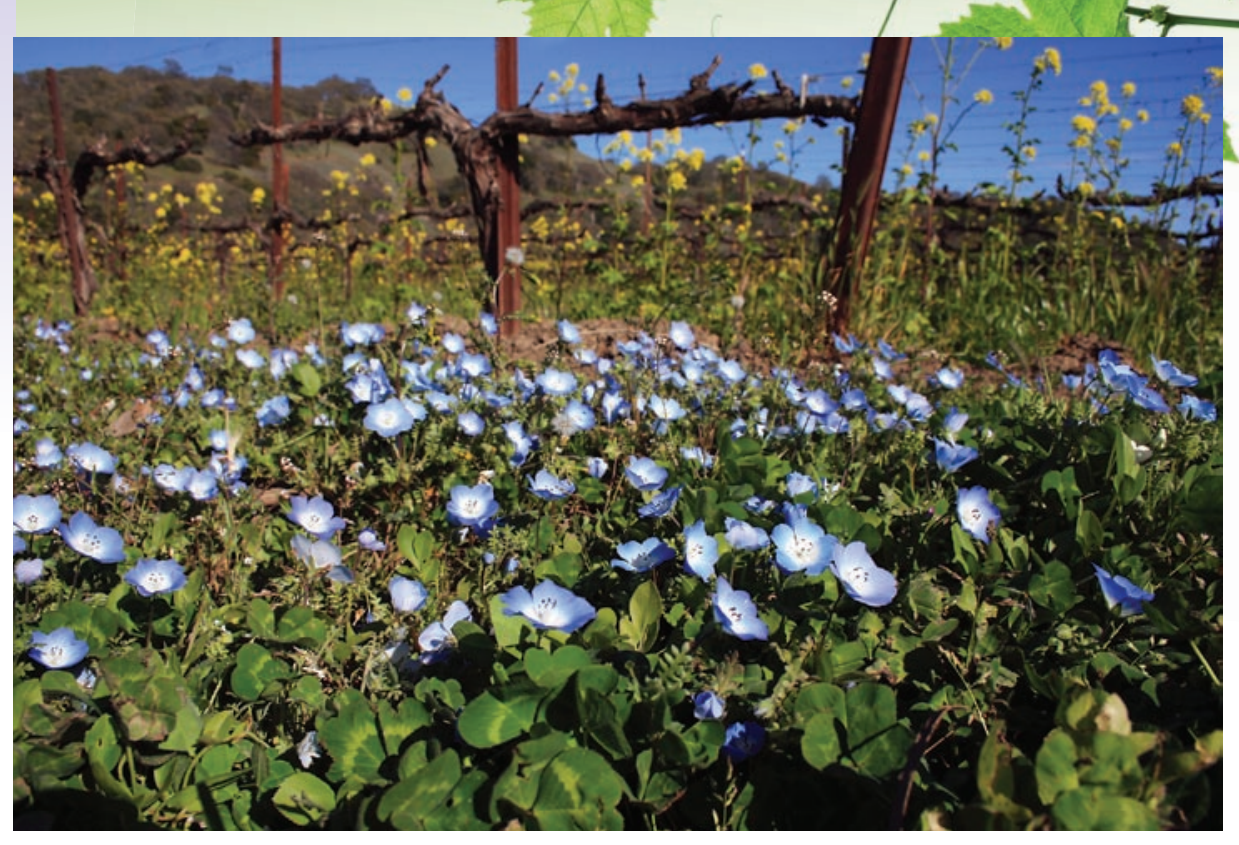

Research shows that low-statured, self-reseeding legumes and grasses may be good cover-crop choices for North Coast vineyards. Above, baby blue bells (Nemophila insignis) and subterranean clover grow in a Lake County organic vineyard.

also aesthetically pleasing, especially those with colorful flowers.

Initially, many cover-crop species used in California vineyards were more appropriate for agronomic-crop farming systems (rotation crops). These species - such as oats (Avena sativa), common vetch (Vicia sativa) and bell beans (Vicia faba) — are large biomass producers and grow up to 48 inches high. As a result, they often contribute excessive soil nitrogen, encouraging unwanted vegetative growth. Most also require tillage for seedbed preparation (Bugg et al. 1996). Since the majority of these cover crops are planted in the fall, soil is exposed when rainfall is most likely, increasing the chances of erosion and water pollution in adjacent surface water (streams, rivers and ponds).

Research by the authors and others has demonstrated that under North Coast conditions, self-reseeding annual legumes and grasses are better choices, since they use less tillage and energy inputs than cover crops that require seedbed preparation and annual seeding. With self-reseeding annual legumes, crop residue from the previous growing season protects the soil from erosion in fall and winter, when seedlings emerge and eventually form a new sward in the vegetated area on the vineyard floor between the vine rows (Bugg et al. 1996; McGourty 1994, 2004).

Vineyard acreage expanded rapidly in Lake County during the late 1990s, resulting in new vine plantings in up- land areas. Otherwise good vineyard sites, many upland locations are at high risk of soil erosion because they are on sloping ground. Many of these new vineyard sites were formerly dryfarmed (nonirrigated) walnut orchards in which orchard floor vegetation was removed to conserve soil moisture, and soil erosion was common in winter. Typically, these new vineyards were planted above 1,400 feet, where winters can be cold (below $18^{\circ} \mathrm{F}$ ) and wet (rainfall averages 35 inches annually, and can total 60 inches in wet years).

Cover crops planted in upland areas must be able to tolerate more extreme conditions than in more temperate lowelevation areas planted to vineyards on the North Coast. In previous covercrop trials in Lake County, medic, rose clover, crimson clover, subterranean clover, balansa clover and Persian clover performed well (McGourty et al. 2006). These cover-crop species often have different winter dormancies (chill-hour requirements to induce flowering and vegetative growth) and potential to produce hard seed (a seedbank that allows self-reseeding in subsequent years).

In previous studies, broad groups of cover crops were evaluated, and their regeneration by self-reseeding was followed for up to two seasons (Bugg et al. 1996; McGourty et al. 2006). In most of these studies, plots were reseeded every year into a tilled seedbed for two consecutive seasons. The trials consistently indicated that low-growing, 

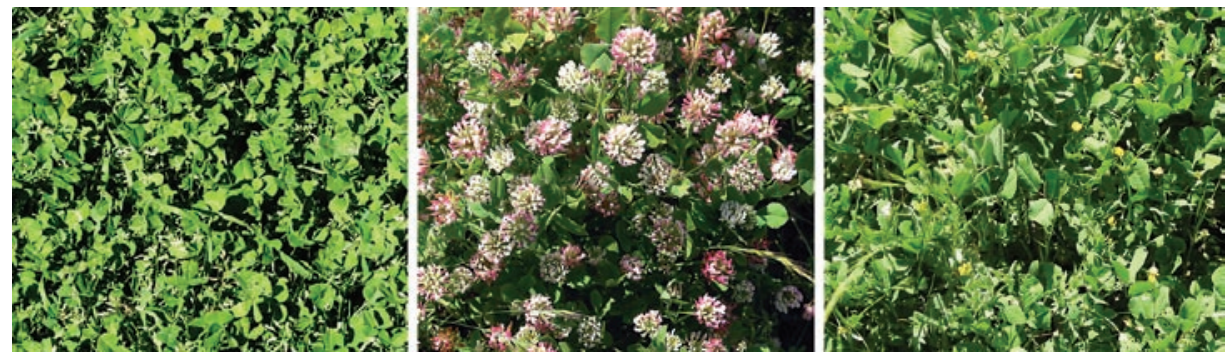

Twenty-two cover-crop cultivars were compared with an unseeded control.

Left, subterranean clover; center, balansa clover; and right, bur medic.

self-reseeding annual legumes such as medic, subterranean clover and other clover species were useful in vineyards as cover crops, even if annual reseeding was required.

This trial was initiated to evaluate the performance of a broader range of cultivars and species of self-reseeding annual clovers. Additionally, we wanted to investigate whether cover crops increased seasonal vineyard water-use. Measurements required to quantify consumptive use were beyond the scope of this work, so we settled on assessing vine water status with pressure chamber measurements to see if vines growing with these cover crops were more stressed than those under tillage. Our goal was to help the many growers who prefer clean tillage (bare soil free of any vegetation) of the vineyard floor during the growing season to determine if the benefits of this strategy, including the conservation of winter rainfall stored in the root zone, were outweighed by potentially increased soil erosion from fall and winter rainfall on the unprotected vineyard floor.

\section{Self-reseeding legumes tested}

Experimental design. A randomized complete block experimental design was used with four replications of each selection for 22 annual legume cultivars and an unseeded control, for a total of 92 plots. The experiment was undertaken in a 1-year-old upland vineyard at 1,400 feet, planted in 2002 to 'Syrah' clone 877 on 101-14 rootstock, with vines spaced 5 feet apart in rows 8 feet apart as dormant bench grafts. The site had formerly been planted to walnut trees for 27 years.

Species. The species evaluated were selected to represent a broad range of winter dormancies and hard-seed production. These species have been used successfully in other agricultural regions with Mediterranean climates as self-reseeding forage crops. Species planted included subterranean clover, medic, Persian clover, balansa clover, crimson clover, rose clover and a control of resident vegetation (table 1). In each replicated plot, the selection was hand-seeded at an appropriately high rate so as not to be a limiting factor (at least 25 pounds per acre) on Oct. 22, 2003 , in two adjacent row middles four vines long (20 feet) by 5 feet wide.

Site preparation. The site was limed at 5 tons per acre before the vines were planted in 2001, resulting in a soil $\mathrm{pH}$ of 6.5. Phosphorus fertilizer with sulfur (0-36-0-20) was applied at 200 pounds per acre to the entire trial to insure that phosphorus and sulfur deficiency would not be a limiting factor to covercrop growth.

Irrigation. The vines were irrigated with a drip system suspended beneath the vines. Two drip emitters with an output of 0.5 gallon per hour each were spaced 2.5 feet apart beneath each vine. Irrigation was applied uniformly to the vineyard at 4 gallons per vine per week. The grower timed each irrigation set, starting and turning off the irrigation pump after precisely 4 hours. In 2004, the vineyard received 12 weekly irrigations beginning July 2 , for a total of 48 gallons per vine. In 2005, the vineyard received 10 weeks of irrigation starting July 14, for a total of 40 gallons per vine.

Harvest measurements. Plots were evaluated and harvested on May 4, 2004. Data taken included percentage of the vineyard-floor plot area covered by each cover crop (visual estimation); height (measured with a yard ruler by taking the average height at four spots); and biomass production (measured by clipping the plant material contained within three 1-foot-square wire frames). Biomass was oven-dried at $120^{\circ} \mathrm{F}$ and weighed. These measure- ments were taken again on May 9, 2005. Only percent-cover estimates were made on May 12, 2006.

Data were analyzed with ANOVA and means were compared with Duncan's multiple range test at the 95\% confidence interval.

Leaf water potential. In 2004 and 2005, leaf-water-potential measurements were made on cloudless days with a pressure bomb by sampling between 11 a.m. and 1 p.m. (full solar noon) using fully expanded, sunlit leaves. Sampling began early in the season, once the cover crops stopped growing and were drying down. In 2004, one replication of each cover crop was chosen at random and a grape leaf was selected from a vine in the center of the plot that had the same cover crop growing in the two adjacent middles to the vine row. Twenty-two vines were chosen in the cover-crop area, and 22 were chosen in an adjacent clean-tilled area of the vineyard. (This was the practical number of samples that could be taken during the solar noon period.)

Leaves were removed, placed in a small plastic bag, inserted into the pressure chamber and secured as quickly as possible. Pressure was applied slowly until sap was extruded from the end of the emerged petiole. The pressure at this point was noted on the gauge of the pressure bomb and recorded. Sampling areas were rotated weekly so that no specific sampling order was followed (i.e., the cover-cropped area was sampled first one week, and the tilled area was sampled first the next week).

Weekly or biweekly observations were made at the same marked vines. When leaf water potential reached more than -13 bars, irrigation was initiated (week 7, June 24, 2004). Leaf water potential was measured until week 10 after two irrigations. Significant precipitation occurred in June 2005 and irrigation was initiated later, since leaf water potential was lower later into the growing season. The sample sizes were reduced to 12 vines in both the covercropped and tilled areas, since fewer plots had successfully regenerated. Monitoring began on July 14,2005 , and the vineyard was irrigated following pressure bomb measurements on July 21. Monitoring continued for 2 more weeks, until Aug. 4. 
Pests. The plots did not have any pest problems such as diseases, mites, insects or vertebrates, and no interventions or treatments were made.

\section{Cover-crop performance}

We found significant differences between many of the cover-crop species in biomass production, plant height and percent cover of the sward (table 1).

Biomass production. Winter 2004 was relatively dry, and precipitation was lower than usual. Rain did not begin until November, and precipitation in March and April was less than 1 inch (23.7 inches for the season). All the cover crops germinated and grew, but overall biomass for the entire trial was lower than in 2005, when precipitation was 2.5 inches in October and almost 5 inches in April and May (26.72 inches for the season). In 2006, total precipitation exceeded 50 inches in the Clear Lake basin.

In 2004, average biomass production was 1.34 tons per acre, ranging from 0.79 ton ('Torreador' medic) to 2.38 tons ('Flame' crimson clover) per acre; by comparison, the resident vegetation (control) produced 0.7 ton per acre. In 2005, average biomass was 2.07 tons per acre, ranging from 1.5 tons ('Santiago' bur medic) to 2.4 tons ('Nitro' Persian clover) per acre, compared to 1.1 tons per acre produced by the resident vegetation.

Biomass is converted into soil carbon over time, which helps to improve soil quality and increase microbial activity, imparting many benefits to the agroecosytem. If a goal of cover crops is to increase biomass grown in the vineyard, then many of the selections performed well compared to resident vegetation. (Nitrogen fertilizer may spur resident vegetation to produce more biomass, but this requires more energy.) Dominant species in the resident vegetation included annual bluegrass (Poa annua), shepherd's purse (Capsella bursa-pastoris), annual ryegrass (Lolium multiflorum), chickweed (Stellaria media), scarlet pimpernel (Anagallis arvensis) and annual sowthistle (Sonchus oleraceus).

Height. All of the cover-crop selections that we studied were low-statured and would not hinder vineyard operations or create high levels of humidity near the vine canopy in late spring (table 1). By contrast, some annual

TABLE 1. Dry weight biomass, height and percent cover of

self-reseeding annual legumes in Lake County, 2004-2006

\begin{tabular}{|c|c|c|c|c|c|c|c|}
\hline \multirow[b]{2}{*}{ Cover crop } & \multicolumn{2}{|c|}{ Biomass } & \multicolumn{2}{|c|}{ Height } & \multicolumn{3}{|c|}{ Cover } \\
\hline & 2004 & 2005 & 2004 & 2005 & 2004 & 2005 & 2006 \\
\hline \multicolumn{8}{|l|}{$\begin{array}{l}\text { Subterranean clovers } \\
\text { (dormancy category)* }^{\text {(dorm }}\end{array}$} \\
\hline Antas (LS) & $1.89 \mathrm{efg} \dagger$ & 2.08 cde & $6.5 a b$ & $10.2 \mathrm{abc}$ & 87.5 def & $85.0 \mathrm{~b}$ & $85.0 \mathrm{~g}$ \\
\hline Campeda (MS) & $1.13 \mathrm{cde}$ & $2.32 \mathrm{def}$ & $4.4 \mathrm{a}$ & $9.0 \mathrm{ab}$ & 73.7 cde & $68.7 \mathrm{ab}$ & $88.7 \mathrm{~g}$ \\
\hline Denmark (LS) & $1.06 \mathrm{cde}$ & 2.40 def & $4.2 \mathrm{a}$ & $10.2 \mathrm{ab}$ & $62.5 \mathrm{bcd}$ & $70.0 \mathrm{ab}$ & $85.0 \mathrm{~g}$ \\
\hline Gosse (MS) & $1.25 \mathrm{cde}$ & $2.14 \mathrm{cde}$ & $4.0 \mathrm{a}$ & $11.2 \mathrm{a}$ & $75.0 \mathrm{cde}$ & $86.2 \mathrm{~b}$ & $82.5 \mathrm{~g}$ \\
\hline Koala (MS) & $0.94 \mathrm{ab}$ & $1.96 \mathrm{bcd}$ & $4.5 \mathrm{a}$ & $7.5 \mathrm{a}$ & $57.5 \mathrm{abc}$ & $61.2 \mathrm{ab}$ & $90.0 \mathrm{~g}$ \\
\hline Mt. Barker (MS) & 1.64 def & 2.54 ef & $4.7 \mathrm{a}$ & $11.2 \mathrm{bc}$ & $92.5 \mathrm{fg}$ & $92.5 \mathrm{c}$ & $87.5 \mathrm{~g}$ \\
\hline Nungarin (ES) & $1.07 \mathrm{bcd}$ & $1.94 \mathrm{bcd}$ & $3.7 \mathrm{a}$ & $8.7 \mathrm{ab}$ & $47.5 \mathrm{a}$ & $60.0 \mathrm{ab}$ & $60.0 \mathrm{de}$ \\
\hline Seaton Park (ES) & $1.06 \mathrm{bcd}$ & $1.66 \mathrm{bc}$ & $3.9 \mathrm{a}$ & $8.5 a b$ & $60.0 \mathrm{bc}$ & $65.0 \mathrm{ab}$ & 73.7 ef \\
\hline Trikkala (MS) & $1.07 \mathrm{bcd}$ & $2.00 \mathrm{bcd}$ & $4.0 \mathrm{a}$ & $8.7 \mathrm{ab}$ & $55.0 \mathrm{ab}$ & $55.0 \mathrm{a}$ & $61.2 \mathrm{de}$ \\
\hline Woogenellup (MS) & $0.96 \mathrm{ab}$ & $1.86 \mathrm{bcd}$ & $3.8 \mathrm{a}$ & $9.0 \mathrm{ab}$ & $67.5 \mathrm{cde}$ & $57.5 \mathrm{ab}$ & 70.0 ef \\
\hline York (ES) & $1.10 \mathrm{bcd}$ & $2.18 \mathrm{cde}$ & $3.8 \mathrm{a}$ & $11.2 \mathrm{bc}$ & 75.0 cde & $85.0 \mathrm{~b}$ & $83.75 \mathrm{~g}$ \\
\hline \multicolumn{8}{|l|}{ Medics } \\
\hline Jester & $1.83 \mathrm{efg}$ & $2.06 \mathrm{cde}$ & $9.0 \mathrm{bc}$ & $10.0 \mathrm{abc}$ & 90.0 efg & $60.0 \mathrm{ab}$ & $35.0 \mathrm{~cd}$ \\
\hline Parabinga & $0.87 a b$ & $2.08 \mathrm{cde}$ & $5.7 \mathrm{a}$ & $10.7 \mathrm{abc}$ & $75.0 \mathrm{cde}$ & $70.0 \mathrm{ab}$ & 70.0 ef \\
\hline Santiago & $1.03 \mathrm{abc}$ & $1.50 \mathrm{bc}$ & $6.4 a b$ & $10.2 \mathrm{abc}$ & 76.3 cde & $73.7 \mathrm{ab}$ & $40.0 \mathrm{~cd}$ \\
\hline Torreador & $0.79 \mathrm{a}$ & $1.58 \mathrm{bc}$ & $5.6 \mathrm{a}$ & $8.5 \mathrm{ab}$ & $52.5 \mathrm{a}$ & $60.0 \mathrm{ab}$ & $86.2 \mathrm{~g}$ \\
\hline \multicolumn{8}{|l|}{ Other clovers } \\
\hline Balansa Bolta & $1.53 \mathrm{def}$ & 2.20 def & $10.8 c$ & $13.2 \mathrm{~cd}$ & $95.0 \mathrm{fg}$ & $82.5 b$ & $80.0 \mathrm{~g}$ \\
\hline Balansa Paradana & 1.60 def & 2.32 def & $11.0 \mathrm{c}$ & $12.0 \mathrm{~cd}$ & $97.5 \mathrm{~h}$ & $86.2 \mathrm{~b}$ & $81.2 \mathrm{~g}$ \\
\hline Crimson Flame & $2.39 \mathrm{i}$ & 2.38 def & $17.0 \mathrm{e}$ & $16.0 \mathrm{e}$ & $97.5 \mathrm{~h}$ & $93.7 c$ & $50.0 \mathrm{de}$ \\
\hline Persian Lightning & $2.10 \mathrm{gh}$ & $2.38 \mathrm{def}$ & $13.6 \mathrm{~d}$ & $12.0 \mathrm{~cd}$ & $100.0 \mathrm{~h}$ & $75.0 \mathrm{~b}$ & $6.2 \mathrm{a}$ \\
\hline Persian Nitro & 1.58 def & 2.40 ef & $9.5 c$ & $11.0 \mathrm{bc}$ & 90.0 efg & $62.5 \mathrm{ab}$ & $27.5 b c$ \\
\hline Rose Hykon & $2.15 \mathrm{gh}$ & $1.88 \mathrm{bcd}$ & $10.5 c$ & $10.7 \mathrm{bc}$ & $97.5 \mathrm{~h}$ & $67.5 \mathrm{ab}$ & $11.2 \mathrm{ab}$ \\
\hline Rose Overton & 1.76 efg & 2.34 def & $9.5 \mathrm{c}$ & $12.2 \mathrm{~cd}$ & $86.2 \mathrm{def}$ & $65.0 \mathrm{ab}$ & $7.7 \mathrm{ab}$ \\
\hline $\begin{array}{l}\text { Control (resident } \\
\text { vegetation) }\end{array}$ & $0.70 \mathrm{a}$ & $1.10 \mathrm{a}$ & $4.1 \mathrm{a}$ & $7.0 \mathrm{a}$ & $100 \mathrm{~h}$ & $100 \mathrm{~d}$ & $100 \mathrm{~h}$ \\
\hline Trialwide average & 1.34 & 2.07 & 6.7 & 10.1 & 74.4 & 68.8 & 59 \\
\hline
\end{tabular}

cover-crop species used in vineyards such as oats (A. fatua), purple vetch ( $V$. benghalensis) and bell (fava) beans can grow up to 4 feet high. In 2004, the average cover-crop height in this trial was 6.7 inches, ranging from 4.0 inches ('Gosse' subterranean clover) to 17.0 inches ('Flame' crimson clover). In 2005, the cover crops grew taller because of increased precipitation. The average height was 10.1 inches, ranging from

7.5 inches ('Koala' subterranean clover) to 16 inches ('Flame' crimson clover).

Cover. Percent cover of the sward measures how successful a species is in germinating and competing with weeds, and how persistent the stand is over time (i.e., how sustainable a planting is). In this trial, cover varied considerably by species (tables 1 and 2). The subterranean clovers increased over time, while medics gradually declined (although 'Torreador' persisted well and increased in percent cover). The other clovers decreased dramatically from 2004 to 2006. Only balansa clover persisted well, with percent covers above $80 \%$ for the two selections after 3 years. We believe that our visual estimations were accurate, but since they may vary by $5 \%$ to $10 \%$, the means comparisons may be overstated in the ANOVA. Nonetheless, percent cover above $70 \%$ indicates that the cover crop has germinated and grown well during that season.

Leaf water potential. Cover-cropping with annual self-reseeding legumes had different effects. In 2004, with its dry spring, there were slight but significant differences between the tilled

\begin{tabular}{|c|c|c|c|}
\hline \multicolumn{4}{|c|}{$\begin{array}{l}\text { TABLE 2. Average percent cover of sward, } \\
\text { 2004-2006 }\end{array}$} \\
\hline Cover crop & 2004 & 2005 & 2006 \\
\hline & \multicolumn{3}{|c|}{$\ldots \ldots \ldots \ldots \% \ldots \ldots \ldots$} \\
\hline $\begin{array}{l}\text { Subterranean } \\
\text { clovers }\end{array}$ & 70 & 70 & 80 \\
\hline Medics & 75 & 65 & 60 \\
\hline Other clovers & 95 & 75 & 40 \\
\hline $\begin{array}{l}\text { Trialwide } \\
\text { average }\end{array}$ & 75 & 75 & 60 \\
\hline
\end{tabular}




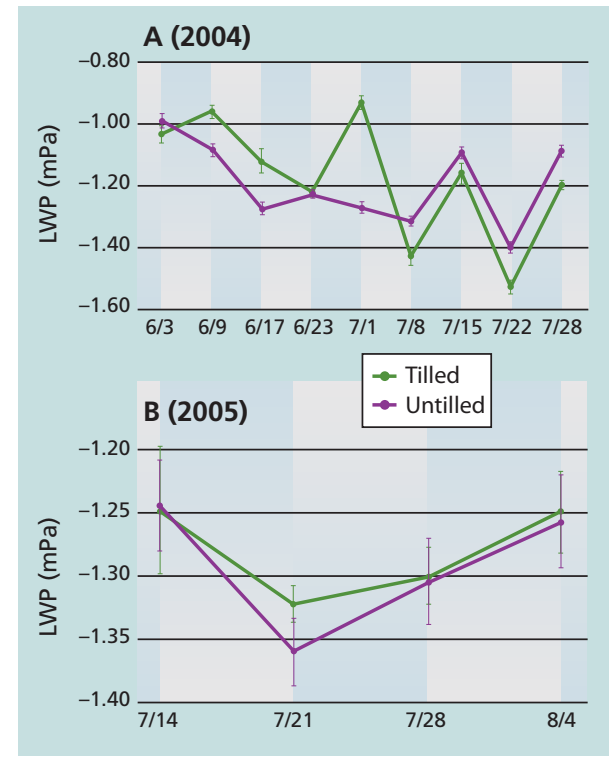

Fig. 1. Leaf water potential (LWP) or vine moisture status in millipascals $(\mathrm{mPa})$, with and without cover crops in (A) 2004 and (B) 2005. "Tilled" means all cover crops were turned under with a disk; "untilled" means the dried aftermath of annual cover crops was left on the surface of the vineyard floor. Tilled, a standard grower practice, is the control. Untilled represents the average of pressure bomb readings taken from all 22 cover crops in 2004. In 2005, readings were taken more randomly within the untilled portion of the trial. In 2004, vines were irrigated during the weeks of July 2 and 22; in 2005, irrigation was during the weeks of July 21 and 28.

and cover-cropped areas (fig. 1). Before irrigation began on July 2, vines in the cover-cropped areas had more negative leaf-water-potential values, indicating that they were under greater water stress. However, after irrigation began, vine water status with the cover crops recovered to a greater extent than with the tilled treatment. The tillage may have caused increased surface evaporation. In 2005 more rain fell in late spring, and there were no significant differences between vine moisture status in the different treatments.

It is not possible to analyze in detail the impact of the different surface treatments on evapotranspiration, since we did not measure the impact of the treatments on the storage of winter rainfall. However, the fact that vine water status with cover crops was only modestly lower than with tillage prior to irrigation, and actually somewhat higher after the 2004 irrigations, indicates that cover-crop water usage did not result in excessive plant water stress. In 2005, there were no significant differences in vine leaf water potential in either the pre- or postirrigation periods (fig. 1). This was likely because there was more rainfall later in the spring and presumably higher soil water levels as the summer progressed in 2005. We conclude that while cover crops certainly consume water, the magnitude of this evapotranspiration must be relatively small and may be offset by improved infiltration and storage of winter rainfall. Additionally, the dried vegetation aftermath in cover-cropped areas offers considerable protection against erosion when fall rains resume, a definite benefit to water quality during winter precipitation.

\section{Choosing cover crops for vineyards}

Numerous species performed well in the initial year of seeding. Top performers for biomass production included the crimson, balansa, rose and subterranean clovers, similar to previous studies (Bugg et al. 1996; McGourty 2006). As a group, the medics did not grow as well as subterranean clovers under Lake County conditions. However, they persisted better than some of the others tested, including Persian, 'Flame' crimson and rose clovers.

Persistence is dependent on the production of hard seed that can survive for several years before germinating, as well as successful germination each season. Subterranean clover has a definite advantage, generating a large amount of hard seed. Most importantly, it can actually preplant its seeds into the ground; seedpods develop on pegs (like peanuts) after flowering, and the seed matures in the soil, protected from feeding by birds and rodents. The seed is then ready to germinate when conditions are optimal.

Balansa clover also performed well, although its percent cover of the sward declined somewhat over time. This species is likely to persist and flowers prolifically, making it potentially useful as an insectary plant for generalist predatory and parasitoid insects and mites.

The cover crops that declined over time in this study were usually displaced by annual weeds also found in the control plots. In our practical experience, it is not unusual for subterranean clover and bur medic stands to increase and decrease over time, since rainfall and distribution can greatly affect seed emergence at the beginning of their growth period in the fall.

All of the species tested are suitable as cover crops for vineyards in the North Coast region, and many performed well at our high-elevation test site. While some may not persist for long, they would still be useful as cover crops even if they require annual reseeding. Subterranean clovers persisted the best of the cover-crop species that we evaluated. Subterranean clovers are categorized by the amount of winter dormancy that is required before vegetative growth and flowering will occur in the spring (table 1). These cultivars with short winter dormancy are best for warm winter areas with limited rainfall, because they complete their growth cycles in less time. Cultivars with longer winter dormancies are best suited for areas with longer winters and more rainfall, and they tend to produce more biomass than cultivars with shorter winter dormancies. Selections from all the dormancy categories also performed well, although in practice, most growers are using long-dormancy selections such as 'Antas', 'Koala' and 'Mt. Barker'.

G. McGourty is Winegrowing and Plant Science Advisor, UC Cooperative Extension (UCCE), Mendocino and Lake counties; J. Nosera is Agricultural Technologist, UCCE Mendocino County; S. Tylicki is General Manager, Steele Wines, Kelseyville, Calif.; and A. Toth is former intern, UCCE Mendocino County. The authors appreciate the cooperation of vineyard owner Jed Steele and assistance of custom farmer Lars Crail. Fred Thomas of Cerus Consulting suggested many of the cover-crop selections. Kamprath Seed Company donated seed for the trial.

\section{References}

Bugg R, McGourty G, Lanini T, et al. 1996. Comparison of 32 cover crops in an organic vineyard on the North Coast of California. Biolog Ag Horticult 13:63-81.

McGourty G.1994. Covercrops for North Coast vineyards. Practical Winery Vineyard 15(2):1-6.

McGourty G. 2004. Covercropping systems for organically farmed vineyards. Practical Winery Vineyard 26(3):22-38.

McGourty G, Tylicki S, Price J, Nosera J. 2006: Performance of 18 cover crop species in a high elevation North Coast vineyard. Practical Winery Vineyard 28(4):10-20 